\title{
Pontibaca methylaminivorans gen. nov., sp. nov., a member of the family Rhodobacteraceae
}

\author{
Kwang Kyu Kim, Jung-Sook Lee, Keun Chul Lee, Hee-Mock Oh \\ and Song-Gun Kim
}

\begin{abstract}
Correspondence
Song-Gun Kim

sgkim@kribb.re.kr
\end{abstract}

\begin{abstract}
Korean Collection for Type Cultures, Biological Resource Center, Korea Research Institute of Bioscience and Biotechnology, 52 Eoeun-dong, Yuseong-gu, Daejeon 305-806, Republic of Korea
\end{abstract}

The family Rhodobacteraceae (Garrity et al., 2005), which belongs to the class Alphaproteobacteria, contains approximately 70 recognized genera (type genus, Rhodobacter) at the time of writing. Nearly three-fifths of the genera in the family Rhodobacteraceae consist of one or two species. Over twothirds of the species within the family originate from marine environments. Several of the genera, including Citreimonas (Choi \& Cho, 2006), Yangia (Dai et al., 2006), Maritimibacter (Lee et al., 2007a), Thalassococcus (Lee et al., 2007b), Tateyamaria (Kurahashi \& Yokota, 2007), Ponticoccus (Hwang \& Cho, 2008) and Pelagicola (Kim et al., 2008), have been described in the last few years.

During a screen for trimethylamine-degrading bacteria from coastal sediments, three organisms were recovered under anaerobic conditions (Kim et al., 2003). Coastal sediment samples from the East Sea, Korea, were initially enriched in mineral salts medium (MSM) supplemented with $10 \mathrm{mM}$ trimethylamine and $30 \mathrm{mM} \mathrm{NaNO}_{3}$ and the cultures were then serially diluted into fresh medium. Aliquots of each serial dilution were spread on MSM agar supplemented with

The GenBank/EMBL/DDBJ accession numbers for the 16S rRNA gene sequences of strains $\mathrm{PH} 34$ and $\mathrm{GRP} 21^{\top}$ are AJ505787 and AJ505788.

A transmission electron micrograph of cells of strain $\mathrm{GRP} 21^{\top}$, an extended neighbour-joining tree, results of TLC of polar lipids and fatty acid profiles at different growth phases are available as supplementary material with the online version of this paper.
$10 \mathrm{mM}$ trimethylamine and $30 \mathrm{mM} \mathrm{NaNO}_{3}$, and incubated anaerobically at $30{ }^{\circ} \mathrm{C}$. Two creamy-white colonies were isolated and subcultured, yielding strains GRP $21^{\mathrm{T}}$ and PH34. On the basis of 16S rRNA gene sequence comparisons, the strains belong to the family Rhodobacteraceae, but they exhibited low levels of 16S rRNA gene sequence similarity, as calculated by the EzTaxon server (Chun et al., 2007), with respect to type strains of representative species such as Donghicola eburneus (94.5\%), Thalassococcus halodurans (94.4\%), Roseivivax halodurans (94.3\%) and Salipiger mucosus (92.4\%). To elucidate the taxonomic status of the two isolates further, they were subjected to a polyphasic investigation.

For most experiments, the strains were cultivated aerobically on tryptic soy agar (Difco) containing $2 \% \mathrm{NaCl}$ or marine agar 2216 (Difco) at $30{ }^{\circ} \mathrm{C}$ for 3 days. For the analysis of fatty acids, the strains were cultivated on tryptic soy agar containing $5 \% \mathrm{NaCl}$ at $30{ }^{\circ} \mathrm{C}$ for 2 days. Donghicola eburneus KCTC $12735^{\mathrm{T}}$, Salipiger mucosus KCTC $22097^{\mathrm{T}}$, Roseivivax halodurans KCTC $22255^{\mathrm{T}}$ and Thalassococcus halodurans KCTC $22637^{\mathrm{T}}$, grown under identical conditions, were used as reference strains for chemotaxonomic analysis and for other phenotypic tests.

Gram-staining was performed as described by Gerhardt et al. (1994). Cell morphology and motility were observed under a light microscope (Nikon Optiphot-2; $\times 1500$ magnification) with cells grown for 3-7 days. Motility was tested by the hanging-drop technique (Skerman, 1967), 
and the presence of flagella was determined by transmission electron microscopy (Philips CM-20) after negative staining with $1 \%(\mathrm{w} / \mathrm{v})$ phosphotungstic acid. Oxidase activity was determined using Bactident Oxidase strips (Merck) and catalase activity was tested using $3 \% \mathrm{H}_{2} \mathrm{O}_{2}$. Growth was investigated at $5,10,15,20,25,30,37$ and $42{ }^{\circ} \mathrm{C}$ and at $\mathrm{pH} 5-11$ (in increments of $1 \mathrm{pH}$ unit) using marine agar 2216 (Difco). The following biological buffers were used to adjust the $\mathrm{pH}: \mathrm{Na}_{2} \mathrm{HPO}_{4} / \mathrm{NaH}_{2} \mathrm{PO}_{4}$ for $\mathrm{pH} 5$ 7 and $\mathrm{Na}_{2} \mathrm{CO}_{3} / \mathrm{NaHCO}_{3}$ for $\mathrm{pH} 8-11$ (Gomori, 1955; Bates \& Bower, 1956). Growth in the absence of $\mathrm{NaCl}$ was investigated using tryptic soy broth prepared according to the Difco recipe with the exception that $\mathrm{NaCl}$ was not included. Growth at various $\mathrm{NaCl}$ concentrations $(0.5 \%$ and $1-15 \%$, at intervals of $1 \%$ ) was investigated in tryptic soy broth (Difco) or marine broth 2216 (Difco) (Yoon et al., 2007). Growth on MacConkey agar (Difco) was tested, and hydrolysis of casein and starch was tested on casein agar and starch agar (both from Difco), respectively; these media were supplemented with $2 \% \mathrm{NaCl}$. In order to test for the presence of bacteriochlorophyll $a$, pigments were extracted from cell pellets with acetone/methanol $(7: 2, \mathrm{v} / \mathrm{v})$ in the dark and the absorption spectrum between 350 and $950 \mathrm{~nm}$ was determined using a Beckman Coulter DU 730 spectrophotometer (Pukall et al., 1999). Tests to determine the utilization of various carbon sources, the production of acid and the physiological profiles of the two strains were performed using the API 20E, API 20NE, API 32GN, API 50CH and API ZYM galleries (bioMérieux) according to the instructions of the manufacturer.

Fatty acid methyl esters were prepared and analysed as described previously (Klatte et al., 1994) using the standard Microbial Identification System (MIDI) for automated gas chromatographic analysis (Sasser, 1990; Kämpfer \& Kroppenstedt, 1996). Isoprenoid quinones were extracted with chloroform/methanol $(2: 1, \mathrm{v} / \mathrm{v})$ and purified using TLC on Kieselgel $60 \mathrm{~F}_{254}$ plates $(20 \times 20 \mathrm{~cm}, 0.5 \mathrm{~mm}$ thick; Merck) with petroleum ether/diethyl ether $(9: 1, \mathrm{v} / \mathrm{v})$ as the solvent. The resulting bands were scraped from the plate under short-wavelength UV light, redissolved in the solvent and concentrated by nitrogen stream evaporation and the quinone profile was then analysed using reversed-phase HPLC (LC20AD system; Shimadzu) as described by Shin et al. (1996). Cell-wall sugars were analysed according to the procedures of Staneck \& Roberts (1974). Polar lipids were extracted, examined using two-dimensional TLC and identified according to published procedures (Minnikin et al., 1977). Results of TLC of polar lipids of GRP $21^{\mathrm{T}}$ and Donghicola eburneus KCTC $12735^{\mathrm{T}}$ are available as Supplementary Fig. S1 in IJSEM Online.

Extraction of genomic DNA, PCR-mediated amplification of the 16S rRNA gene and sequencing of purified PCR products were carried out according to Rainey et al. (1996) with the exception that the Prep-A-gene kit (Bio-Rad) was not used for further purification of the DNA. 16S rRNA gene sequences were aligned with published sequences retrieved from EMBL using CLUSTAL_X (Thompson et al., 1997) and were edited using BioEdit (Hall, 1999). Phylogenetic trees were constructed using sequences of approximately $1300 \mathrm{bp}$ on the basis of the neighbour-joining (Saitou \& Nei, 1987) and maximum-parsimony (Fitch, 1971) methods. Distances were estimated by the method of Jukes \& Cantor (1969) using the program MEGA version 4.0 (Kumar et al., 2007). For phylogenetic analysis based on the maximum-likelihood algorithm, the PHYLIP package version 3.67 (Felsenstein, 2004) was used. The resultant tree topologies were evaluated by means of bootstrap analysis (Felsenstein, 1985) based on 1000 resampled datasets for the MEGA trees or 100 datasets for the PHYLIP trees. DNA G $+C$ content was determined by HPLC after hydrolysis, as described by Tamaoka \& Komagata (1984), and non-methylated lambda phage DNA (Sigma) was used as the standard. DNA-DNA hybridization was performed fluorometrically (Ezaki et al., 1989) using DNA probes labelled with photobiotin (Sigma) in 96-well microdilution plates (Greiner Bio-One) at $50{ }^{\circ} \mathrm{C}$.

Strains GRP21 ${ }^{\mathrm{T}}$ and PH34 formed visible colonies (approx. $0.5 \mathrm{~mm}$ in diameter) within 3 days on tryptic soy agar containing $2 \% \mathrm{NaCl}$ or marine agar 2216. Growth occurred at $15-37{ }^{\circ} \mathrm{C}$, but no growth was observed below $10{ }^{\circ} \mathrm{C}$ or at $42{ }^{\circ} \mathrm{C}$ within 14 days. Growth occurred at $\mathrm{pH} 6-10$. Cells of the two strains were Gram-negative, non-motile, facultatively anaerobic, slightly halophilic, oval-shaped rods and the colonies were creamy white. The strains were able to reduce nitrate or nitrite, allowing them to grow under anaerobic conditions. A transmission electron micrograph of cells of strain GRP $21^{\mathrm{T}}$ is available as Supplementary Fig. S2.

The almost-complete 16S rRNA gene sequences (approx. $1400 \mathrm{bp}$ ) of strains GRP $21^{\mathrm{T}}$ and PH 34 were determined and compared with those of representative species of the genera within the family Rhodobacteraceae. Strains GRP $21^{\mathrm{T}}$ and PH34 shared $99.4 \% 16 \mathrm{~S}$ rRNA gene sequence similarity. They showed the highest level of similarity (94.5\%) to Donghicola eburneus KCTC $12735^{\mathrm{T}}$, as calculated by the EzTaxon server (http://www.eztaxon.org/). In the phylogenetic tree, strains GRP $21^{\mathrm{T}}$ and PH34 occupy a distinct position within the family Rhodobacteraceae, forming a branch with Donghicola eburneus and Thalassococcus halodurans (Fig. 1 and Supplementary Fig S3). DNA-DNA hybridization between strains GRP $21^{\mathrm{T}}$ and PH 34 was $93 \%$, confirming that they belong to the same genomic species (Wayne et al., 1987).

Strains GRP21 ${ }^{\mathrm{T}}$ and PH34 were clearly differentiated from related species by the presence of $19: 0$ cyclo $\omega 8 c(16 \%)$ as one of the major fatty acids. The dominant fatty acid of related taxa in the family Rhodobacteraceae is $18: 1 \omega 7 c$, at more than $70 \%$, while this fatty acid made up about $50 \%$ of the total in strains GRP21 ${ }^{\mathrm{T}}$ and PH34 (Table 1). The fatty acid 19:0 cyclo $\omega 8 c$ was absent from Donghicola eburneus and Thalassococcus halodurans but was found as a minor component in Salipiger mucosus and Roseivivax halodurans as well as being found in Oceanicola granulosus (10.8\%; Cho \& Giovannoni, 2004), Citreimonas salinaria (20.4\%; Choi \& 


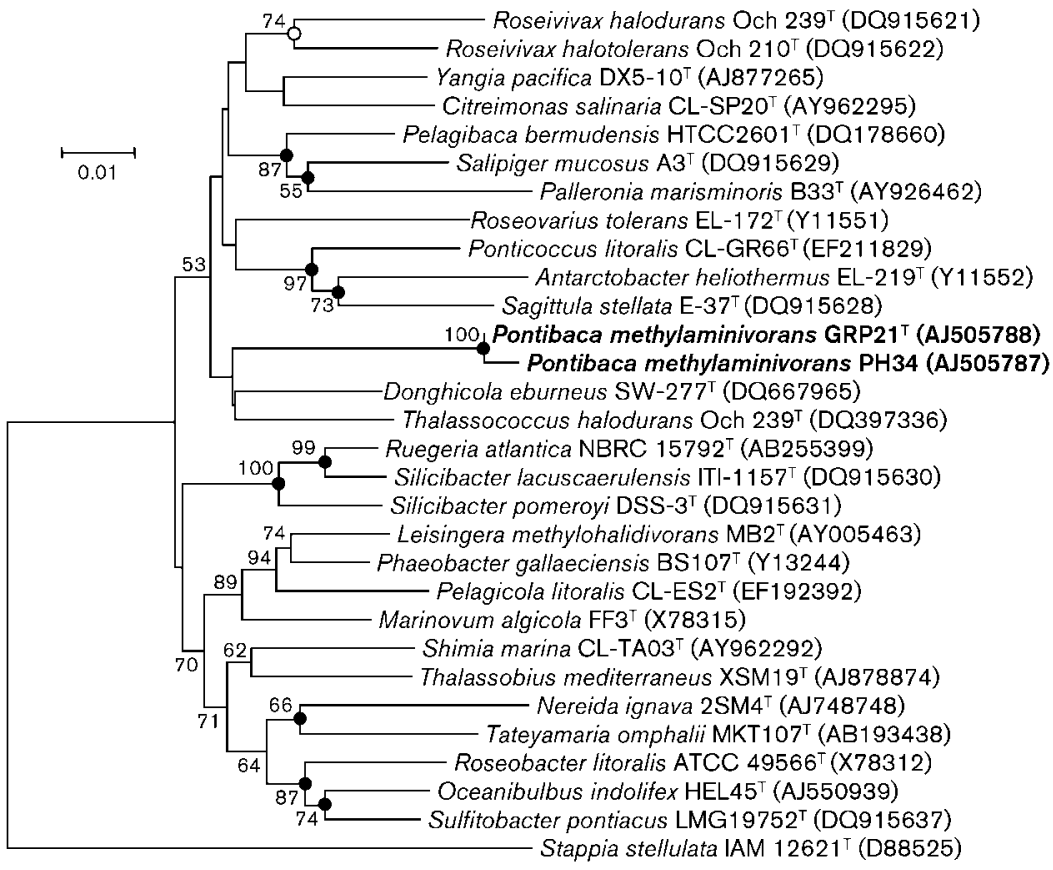

Fig. 1. Phylogenetic tree based on $16 \mathrm{~S}$ rRNA gene sequences, constructed according to the neighbour-joining method, showing the positions of strains $\mathrm{GRP} 21^{\top}$ and $\mathrm{PH} 34$ among representative species within the family Rhodobacteraceae. Numbers at branch points refer to bootstrap values (percentages of 1000 resamplings; only values above $50 \%$ are shown). Stappia stellulata IAM $12621^{\top}$ was used to root the tree. Solid circles indicate branches that were found in both the maximum-likelihood and maximum-parsimony trees (bootstrap values $>50 \%$ ). The open circle indicates a branch point that was recovered only in the maximum-parsimony tree (bootstrap value $>50 \%$ ). Bar, 1 substitution per 100 nucleotide positions. An extended neighbourjoining tree including GRP $21^{\top}$ and almost all type species in the family Rhodobacteraceae is available as Supplementary Fig. S3.

Cho, 2006) and Tateyamaria omphalii (7.6\%; Kurahashi \& Yokota, 2007). The dependence of the fatty acid composition on the growth phase of strain GRP $21^{\mathrm{T}}$ was tested (Supplementary Table S1). The percentage of 19:0 cyclo $\omega 8$ c increased and that of $18: 1 \omega 7 c$ decreased with length of cultivation, but

Table 1. Cellular fatty acids of strains $\mathrm{GRP} 21^{\top}$ and $\mathrm{PH} 34$ and the type strains of related species

Strains: 1, GRP21 ${ }^{\mathrm{T}}$; 2, PH34; 3, Donghicola eburneus KCTC $12735^{\mathrm{T}}$; 4 , Thalassococcus halodurans KCTC $22637^{\mathrm{T}}$; 5, Salipiger mucosus KCTC $22097^{\mathrm{T}} ; 6$, Roseivivax halodurans $\mathrm{KCTC} 22255^{\mathrm{T}}$. Fatty acid compositions were analysed in this study with cells grown on tryptic soy agar for 2 days. Fatty acids are listed using standard abbreviations (number of carbon atoms: number of double bonds). Values are percentages of total fatty acids. ND, Not detected.

\begin{tabular}{|lcccccc|}
\hline Fatty acid & $\mathbf{1}$ & $\mathbf{2}$ & $\mathbf{3}$ & $\mathbf{4}$ & $\mathbf{5}$ & $\mathbf{6}$ \\
\hline $10: 03-\mathrm{OH}$ & 2.6 & 2.4 & 0.7 & 1.7 & $\mathrm{ND}$ & $\mathrm{ND}$ \\
$12: 0$ & 3.1 & 3.3 & $\mathrm{ND}$ & $\mathrm{ND}$ & $\mathrm{ND}$ & $\mathrm{ND}$ \\
$12: 13-\mathrm{OH}$ & $\mathrm{ND}$ & $\mathrm{ND}$ & 3.3 & 5.1 & 5.4 & $\mathrm{ND}$ \\
$12: 03-\mathrm{OH}$ & 3.6 & 3.3 & $\mathrm{ND}$ & 0.1 & 0.4 & 3.5 \\
$14: 0$ & 0.6 & 0.5 & $\mathrm{ND}$ & 0.1 & $\mathrm{ND}$ & $\mathrm{ND}$ \\
Summed feature $4^{*}$ & 0.9 & 0.7 & 1.0 & 0.7 & 1.6 & $\mathrm{ND}$ \\
$16: 0$ & 15.8 & 14.9 & 6.4 & 7.1 & 16.9 & 3.4 \\
$17: 0$ & 0.7 & 0.5 & $\mathrm{ND}$ & 0.7 & $\mathrm{ND}$ & 0.6 \\
$18: 1 \omega 9 c$ & $\mathrm{ND}$ & $\mathrm{ND}$ & $\mathrm{ND}$ & 0.5 & $\mathrm{ND}$ & $\mathrm{ND}$ \\
$18: 1 \omega 7 c$ & 51.1 & 48.8 & 84.8 & 77.7 & 70.7 & 74.2 \\
$18: 0$ & 2.1 & 2.1 & 3.8 & 4.8 & 1.4 & 13.4 \\
$11-$ Methyl $18: 1 \omega 7 c$ & 0.9 & 0.8 & $\mathrm{ND}$ & 0.9 & 2.4 & 0.9 \\
$19: 0$ cyclo $\omega 8 c$ & 16.1 & 16.5 & $\mathrm{ND}$ & $\mathrm{ND}$ & 1.3 & 1.8 \\
& & & & & & \\
\hline
\end{tabular}

${ }^{\star}$ Summed feature 4 comprises $16: 1 \omega 7 c$ and/or iso-15:0 2-OH. cells harvested at early exponential growth (day 2) already contained 19:0 cyclo $\omega 8 c$. We therefore conclude that the presence of 19:0 cyclo $\omega 8 \mathrm{c}$ is a distinct characteristic of the fatty acid compositions of GRP $21^{\mathrm{T}}$ and PH34.

The physiological, biochemical and chemotaxonomic characteristics of strains GRP $21^{\mathrm{T}}$ and PH 34 are given in the species description and characteristics that serve to distinguish these strains from their closest phylogenetic neighbours, Donghicola eburneus and Thalassococcus halodurans, and related taxa are listed in Tables 1 and 2. Significant differences in terms of profiles of fatty acids, acid production, carbon source utilization and substrate hydrolysis, cell morphology, anaerobic growth and nitrite reduction support the proposal of a novel genus.

On the basis of 16S rRNA gene dissimilarity with respect to related taxa, together with the phylogenetically distinct position, unique phenotypic characteristics and genomic relatedness, strains GRP2 $1^{\mathrm{T}}$ and $\mathrm{PH} 34$ represent a novel genus and species, for which the name Pontibaca methylaminivorans gen. nov., sp. nov. is proposed.

\section{Description of Pontibaca gen. nov.}

Pontibaca [Pon.ti.ba'ca. L. n. pontus the sea; L. fem. n. baca a berry, especially an olive; N.L. fem. n. Pontibaca oliveshaped (bacterium) of the sea].

Cells are Gram-negative, non-motile, facultatively anaerobic, oval-shaped rods. Slightly halophilic. Bacteriochlorophyll $a$ is not produced. Nitrate and nitrite are reduced. Catalase- and oxidase-positive. Major polar lipids are phosphatidylcholine and phosphatidylglycerol. Major fatty acids are 16:0, 18: $1 \omega 7 c$ and $19: 0$ cyclo $\omega 8 c$ (together representing $83 \%$ of the total in the type strain of the type species). The 
Table 2. Characteristics that differentiate strains $\mathrm{GRP} 21^{\top}$ and $\mathrm{PH} 34$ from representatives of related genera

Strains: 1, GRP21 ${ }^{\mathrm{T}}$ and PH34 (Pontibaca methylaminivorans gen. nov., sp. nov.); 2, Donghicola eburneus SW-277 ${ }^{\mathrm{T}}$; 3 , Thalassococcus halodurans UST050418$052^{\mathrm{T}}$ (data from Lee et al., 2007b); 4, Salipiger mucosus $\mathrm{A}^{\mathrm{T}}$; 5 , Roseivivax halodurans Och $239^{\mathrm{T}}$. Data were obtained in the present study unless indicated. All strains are positive for catalase and oxidase activities and have ubiquinone Q-10 as the major quinone. +, Positive; -, negative; NA, no data available.

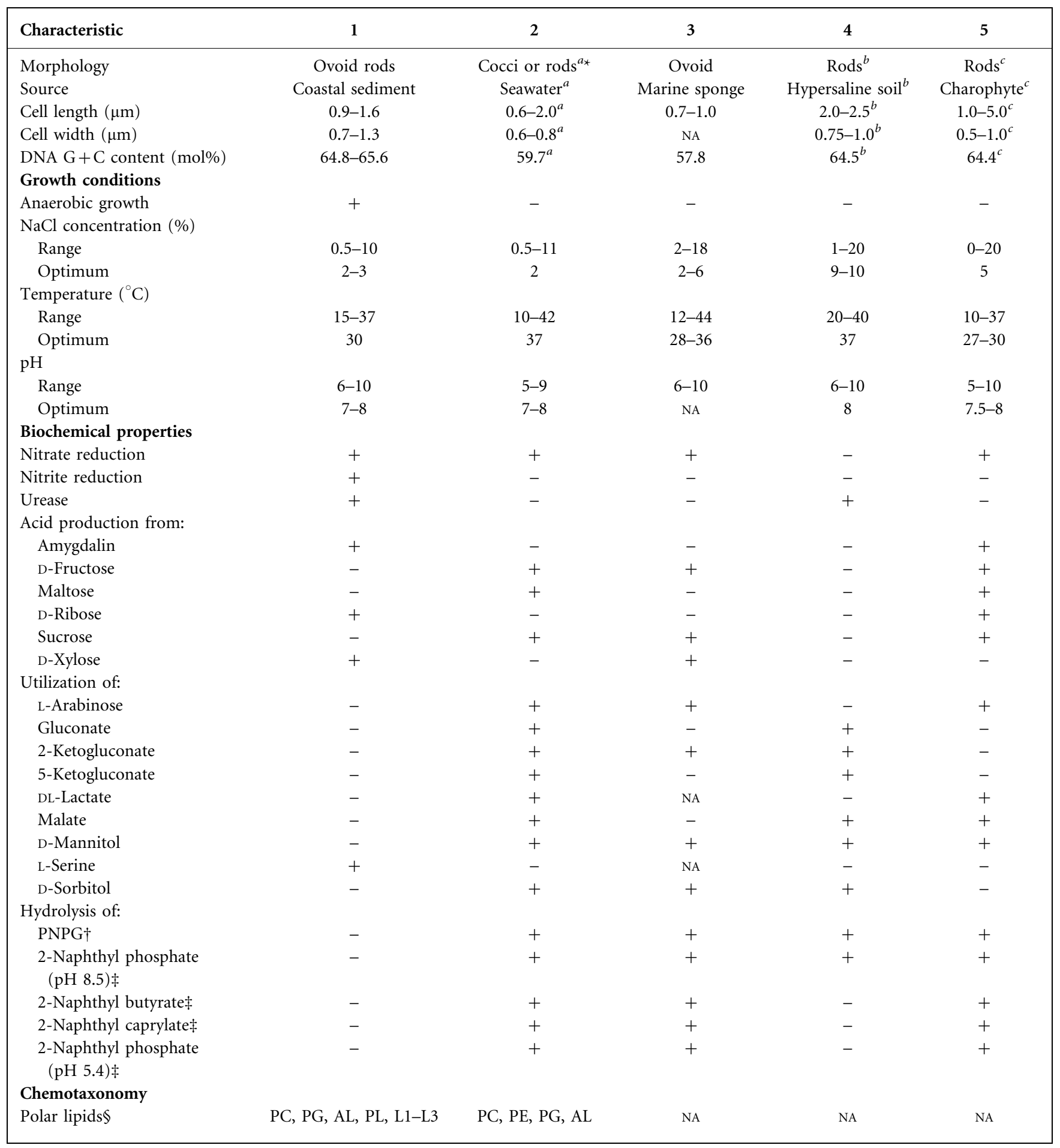

${ }^{*}$ Data from: $a$, Yoon et al. (2007); b, Martínez-Cánovas et al. (2004); c, Suzuki et al. (1999).

$\dagger p$-Nitrophenyl $\beta$-D-galactopyranoside.

$\ddagger$ Data from API ZYM tests. The intensity of the colour was measured on a scale from 0 to 5 and was interpreted as negative at values of 0 or 1 and positive at values of $2-5$.

§PC, Phosphatidylcholine; PE, phosphatidylethanolamine; PG, phosphatidylglycerol; AL, unknown aminolipid; PL, unknown phospholipid; L1-3, unknown polar lipids. 
predominant respiratory quinone is ubiquinone Q-10. The type species is Pontibaca methylaminivorans.

\section{Description of Pontibaca methylaminivorans sp. nov.}

Pontibaca methylaminivorans (me.thy'la.mi'ni.vo'rans. N.Gr. n. methyl the methyl radical; N.L. n. aminum the amine group; L. part. pres. vorans devouring; N.L. part. adj. methylaminivorans degrading methylated amines).

Displays the following properties in addition to those given for the genus. Cells are $0.7-1.3 \times 0.9-1.6 \mu \mathrm{m}$. Colonies are circular, convex and creamy white. Growth occurs at 15$37{ }^{\circ} \mathrm{C}$ (optimum $30{ }^{\circ} \mathrm{C}$ ), at $\mathrm{pH}$ 6-10 (optimum pH 7-8) and at $0.5-10 \% \mathrm{NaCl}$ (optimum $2-3 \%$ ). No growth is observed on MacConkey agar. Indole and $\mathrm{H}_{2} \mathrm{~S}$ are not produced. Urease is produced, but arginine dihydrolase, lysine decarboxylase, ornithine decarboxylase and $\beta$ galactosidase are not. Aesculin, casein, gelatin and starch are not hydrolysed. The Voges-Proskauer test is positive. In the API $50 \mathrm{CH}$ gallery, acid is produced from amygdalin, D- and L-arabinose, cellobiose, D-fucose, D-galactose, Dglucose, lactose, D-mannose, melibiose, L-rhamnose, Dribose and D- and L-xylose, but not from $\mathrm{N}$-acetylglucosamine, adonitol, D- or L-arabitol, arbutin, dulcitol, erythritol, D-fructose, L-fucose, gentiobiose, gluconate, glycerol, glycogen, myo-inositol, inulin, 2- or 5-ketogluconate, D-lyxose, maltose, D-mannitol, melezitose, methyl $\alpha$ D-glucoside, methyl $\alpha$-D-mannoside, methyl $\beta$-D-xyloside, raffinose, D-salicin, D-sorbitol, sorbose, starch, sucrose, Dtagatose, trehalose, turanose or xylitol. Acetate, 3-hydroxybutyrate and L-serine are utilized as sole carbon sources, but $\mathrm{N}$-acetylglucosamine, adipate, L-alanine, L-arabinose, caprate, citrate, L-fucose, gluconate, D-glucose, glycogen, Lhistidine, 3- and 4-hydroxybenzoate, myo-inositol, itaconate, 2- and 5-ketogluconate, DL-lactate, malate, malonate, maltose, D-mannitol, D-mannose, melibiose, phenylacetate, L-proline, propionate, L-rhamnose, D-ribose, D-salicin, D-sorbitol, suberate, sucrose and valerate are not. Trimethylamine, dimethylamine, methylamine and tetramethylammonium are utilized as sole carbon sources under both aerobic and anaerobic conditions. According to API ZYM tests, L-leucyl 2-naphthylamide and L-valyl 2-naphthylamide are hydrolysed, but 2-naphthyl phosphate $(\mathrm{pH} 8.5$ and 5.4), 2-naphthyl butyrate, 2-naphthyl caprylate, 2naphthyl myristate, L-cystyl 2-naphthylamide, $N$-benzoylDL-arginine 2-naphthylamide, $\mathrm{N}$-glutaryl-phenylalanine 2-naphthylamide, naphthol-AS-BI-phosphate, 6-bromo-2naphthyl $\alpha$-D-galactopyranoside, 2 -naphthyl $\beta$-D-galactopyranoside, naphthol-AS-BI $\beta$-D-glucuronide, 2-naphthyl $\alpha$-D-glucopyranoside, 6-bromo-2-naphthyl $\beta$-D-glucopyranoside, 1-naphthyl $N$-acetyl- $\beta$-D-glucosaminide, 6-bromo2 -naphthyl $\alpha$-D-mannopyranoside and 2-naphthyl $\alpha$-Lfucopyranoside are not hydrolysed. The polar lipids are composed of phosphatidylcholine, phosphatidylglycerol, an unknown aminolipid, an unknown phospholipid and three unknown polar lipids. The cell-wall sugars are galactose and glucose. The $\mathrm{G}+\mathrm{C}$ content of the DNA is $64.8-65.6 \mathrm{~mol} \%$ (64.8 $\mathrm{mol} \%$ for the type strain).

The type strain is GRP $21^{\mathrm{T}}\left(=\mathrm{KCTC} 22497^{\mathrm{T}}=\mathrm{DSM}\right.$ $\left.21219^{\mathrm{T}}\right)$, isolated from a coastal sediment.

\section{Acknowledgements}

This work was supported by a grant from the KRIBB Research Initiative Program.

\section{References}

Bates, R. G. \& Bower, V. E. (1956). Alkaline solutions for pH control. Anal Chem 28, 1322-1324.

Cho, J.-C. \& Giovannoni, S. J. (2004). Oceanicola granulosus gen. nov., sp. nov. and Oceanicola batsensis sp. nov., poly- $\beta$-hydroxybutyrateproducing marine bacteria in the order 'Rhodobacterales'. Int J Syst Evol Microbiol 54, 1129-1136.

Choi, D. H. \& Cho, B. C. (2006). Citreimonas salinaria gen. nov., sp. nov., a member of the Roseobacter clade isolated from a solar saltern. Int J Syst Evol Microbiol 56, 2799-2803.

Chun, J., Lee, J.-H., Jung, Y., Kim, M., Kim, S., Kim, B. K. \& Lim, Y. W. (2007). EzTaxon: a web-based tool for the identification of prokaryotes based on $16 \mathrm{~S}$ ribosomal RNA gene sequences. Int J Syst Evol Microbiol 57, 2259-2261.

Dai, X., Wang, B.-J., Yang, Q.-X., Jiao, N.-Z. \& Liu, S.-J. (2006). Yangia pacifica gen. nov., sp. nov., a novel member of the Roseobacter clade from coastal sediment of the East China Sea. Int J Syst Evol Microbiol 56, 529-533.

Ezaki, T., Hashimoto, Y. \& Yabuuchi, E. (1989). Fluorometric deoxyribonucleic acid-deoxyribonucleic acid hybridization in microdilution wells as an alternative to membrane filter hybridization in which radioisotopes are used to determine genetic relatedness among bacterial strains. Int J Syst Bacteriol 39, 224-229.

Felsenstein, J. (1985). Confidence limits on phylogenies: an approach using the bootstrap. Evolution 39, 783-791.

Felsenstein, J. (2004). PHYLIP (phylogeny inference package), version 3.6. Distributed by the author. Department of Genome Sciences, University of Washington, Seattle, USA.

Fitch, W. M. (1971). Toward defining the course of evolution: minimum change for a specific tree topology. Syst Zool 20, 406-416.

Garrity, G. M., Bell, J. A. \& Lilburn, T. (2005). Family I. Rhodobacteraceae fam. nov. In Bergey's Manual of Systematic Bacteriology, 2nd edn, vol. 2C, p. 161. Edited by D. J. Brenner, N. R. Krieg, J. T. Staley \& G. M. Garrity. New York: Springer.

Gerhardt, P., Murray, R. G. E., Wood, W. A. \& Krieg, N. R. (editors) (1994). Methods for General and Molecular Bacteriology. Washington, DC: American Society for Microbiology.

Gomori, G. (1955). Preparation of buffers for use in enzyme studies. Methods Enzymol 1, 138-146.

Hall, T. A. (1999). BioEdit: a user-friendly biological sequence alignment editor and analysis program for Windows 95/98/NT. Nucleic Acids Symp Ser 41, 95-98.

Hwang, C. Y. \& Cho, B. C. (2008). Ponticoccus litoralis gen. nov., sp. nov., a marine bacterium in the family Rhodobacteraceae. Int J Syst Evol Microbiol 58, 1332-1338.

Jukes, T. H. \& Cantor, C. R. (1969). Evolution of protein molecules. In Mammalian Protein Metabolism, vol. 3, pp. 21-132. Edited by H. N. Munro. New York: Academic Press. 
Kämpfer, P. \& Kroppenstedt, R. M. (1996). Numerical analysis of fatty acid patterns of coryneform bacteria and related taxa. Can $J$ Microbiol 42, 989-1005.

Kim, S.-G., Bae, H.-S., Oh, H.-M. \& Lee, S.-T. (2003). Isolation and characterization of novel halotolerant and/or halophilic denitrifying bacteria with versatile metabolic pathways for the degradation of trimethylamine. FEMS Microbiol Lett 225, 263-269.

Kim, Y.-G., Hwang, C. Y. \& Cho, B. C. (2008). Pelagicola litoralis gen. nov., sp. nov., isolated from coastal water in Korea. Int J Syst Evol Microbiol 58, 2102-2104.

Klatte, S., Rainey, F. A. \& Kroppenstedt, R. M. (1994). Transfer of Rhodococcus aichiensis Tsukamura 1982 and Nocardia amarae Lechevalier and Lechevalier 1974 to the genus Gordona as Gordona aichiensis comb. nov. and Gordona amarae comb. nov. Int J Syst Bacteriol 44, 769-773.

Kumar, S., Dudley, J., Nei, M. \& Tamura, K. (2007). MEGA4: molecular evolutionary genetics analysis (MEGA) software version 4.0. Mol Biol Evol 24, 1596-1599.

Kurahashi, M. \& Yokota, A. (2007). Tateyamaria omphalii gen. nov., sp. nov., an $\alpha$-proteobacterium isolated from a top shell Omphalius pfeifferi pfeifferi. Syst Appl Microbiol 30, 371-375.

Lee, K., Choo, Y.-J., Giovannoni, S. J. \& Cho, J.-C. (2007a). Maritimibacter alkaliphilus gen. nov., sp. nov., a genome-sequenced marine bacterium of the Roseobacter clade in the order Rhodobacterales. Int J Syst Evol Microbiol 57, 1653-1658.

Lee, O. O., Tsoi, M. M. Y., Li, X., Wong, P.-K. \& Qian, P.-Y. (2007b). Thalassococcus halodurans gen. nov., sp. nov., a novel halotolerant member of the Roseobacter clade isolated from the marine sponge Halichondria panicea at Friday Harbor, USA. Int J Syst Evol Microbiol 57, 1919-1924.

Martínez-Cánovas, M. J., Quesada, E., Martínez-Checa, F., del Moral, A. \& Béjar, V. (2004). Salipiger mucescens gen. nov., sp. nov., a moderately halophilic, exopolysaccharide-producing bacterium isolated from hypersaline soil, belonging to the $\alpha$-Proteobacteria. Int J Syst Evol Microbiol 54, 1735-1740.

Minnikin, D. E., Patel, P. V., Alshamaony, L. \& Goodfellow, M. (1977). Polar lipid composition in the classification of Nocardia and related bacteria. Int J Syst Bacteriol 27, 104-117.

Pukall, R., Buntefuß, D., Frühling, A., Rohde, M., Kroppenstedt, R. M., Burghardt, J., Lebaron, P., Bernard, L. \& Stackebrandt, E. (1999).
Sulfitobacter mediterraneus sp. nov., a new sulfite-oxidizing member of the $\alpha$-Proteobacteria. Int J Syst Bacteriol 49, 513-519.

Rainey, F. A., Ward-Rainey, N., Kroppenstedt, R. M. \& Stackebrandt, E. (1996). The genus Nocardiopsis represents a phylogenetically coherent taxon and a district actinomycete lineage: proposal of Nocardiopsaceae fam. nov. Int J Syst Bacteriol 46, 1088-1092.

Saitou, N. \& Nei, M. (1987). The neighbor-joining method; a new method for reconstructing phylogenetic trees. Mol Biol Evol 4, 406425.

Sasser, M. (1990). Identification of bacteria by gas chromatography of cellular fatty acids. MIDI Technical Note 101. Newark, DE: MIDI Inc.

Shin, Y. K., Lee, J.-S., Chun, C. O., Kim, H.-J. \& Park, Y.-H. (1996). Isoprenoid quinone profiles of Leclercia adecarboxylata KCTC $1036^{\mathrm{T}}$. J Microbiol Biotechnol 6, 68-69.

Skerman, V. B. D. (1967). A Guide to the Identification of the Genera of Bacteria, 2nd edn. Baltimore: Williams \& Wilkins.

Staneck, J. L. \& Roberts, G. D. (1974). Simplified approach to identification of aerobic actinomycetes by thin-layer chromatography. Appl Microbiol 28, 226-231.

Suzuki, T., Muroga, Y., Takahama, M. \& Nishimura, Y. (1999). Roseivivax halodurans gen. nov., sp. nov. and Roseivivax halotolerans sp. nov., aerobic bacteriochlorophyll-containing bacteria isolated from a saline lake. Int J Syst Bacteriol 49, 629-634.

Tamaoka, J. \& Komagata, K. (1984). Determination of DNA base composition by reversed-phase high-performance liquid chromatography. FEMS Microbiol Lett 25, 125-128.

Thompson, J. D., Gibson, T. J., Plewniak, F., Jeanmougin, F. \& Higgins, D. G. (1997). The CLUSTAL_X windows interface: flexible strategies for multiple sequence alignment aided by quality analysis tools. Nucleic Acids Res 25, 4876-4882.

Wayne, L. G., Brenner, D. J., Colwell, R. R., Grimont, P. A. D., Kandler, O., Krichevsky, M. I., Moore, L. H., Moore, W. E. C., Murray, R. G. E. \& other authors (1987). International Committee on Systematic Bacteriology. Report of the ad hoc committee on reconciliation of approaches to bacterial systematics. Int J Syst Bacteriol 37, 463-464.

Yoon, J.-H., Kang, S.-J. \& Oh, T.-K. (2007). Donghicola eburneus gen. nov., sp. nov., isolated from seawater of the East Sea in Korea. Int $J$ Syst Evol Microbiol 57, 73-76. 